機械・構造物の信頼性設計

\title{
5. 故障物理と信頼性理論*
}

\author{
中川隆 夫** 福田収 一***
}

\section{1 故障物理の認識}

機械や構造物を設計するとき，まずニーザーからの 要求性能を満すことはもちろんであるが, それらが使 用期間中, 故障や破損なく, 安全にその使命を果すこ とも重要である.このため, 強度に関する設計では, 古来, 安全率が用いられてきた。この安全率は部材の 強度と設計応力との比として定義され, 種々の場合に 応じて経験から出されたものであったが,きわめてあ いまいであり，その值のとりかたは設計者に委ねられ ていた、それゆ光，安全率を大きくとったためにか觉 って信頼感をもたれないことも起っており, “不安全 係数”とか “ignorance factor” という皮肉な言いか たをされたこともあった. 安全率は決して安全の度合 を示しているものではなく, 安全確保のために余裕を とっておくというものに過ぎない. 信頼性工学は安全 率を故障や破壊の確率と結びつけ, さらに安全率に代 って破壞確率または信頼度を安全性の尺度にとろうと するものである.

信頼性工学は電気・電子工業の分野で早くから発達 し, 製品やシステムの品質管理, 故障修理, メンテナ ンス, 寿命と信頼度などに関し, その安全性の評価と 改善に重要な役割を果してきた。次いで土木や建筑な ぞの構造物や造船の分野で発達し, さらに現在圧力容 器や機械の分野の設計に採り入れられよらとしている. 電子工業では, 製品の使用やシステムの作動は比較的 一定の条件で行われ，その故障や破壊のモードも大体 一定であり, また, スイッチやリレ一等, ある機能を 果す物理的実体がそれぞれ独立に存在し，それら機能 素子間の相互干渉もほとんどないか，たと充竹っても 比較的単純であり，その関係の把握が比較的容易であ るが, 機械や構造物では, 製品の特性のばらつきの甚 しさに加觉て, 外乱 (負荷) の確率的変動もあり, 故 障や破損にも多様性があり, かつ機能素子間の相互干 涉が著しく, その関係の把握も容易ではない。したが って故障物理を認識しない単なる統計的処理では母集

* 原稿受理 昭和57年 2 月 19 日

** 正 会員 神戸大学工学部 神戸市灘区六甲台町

*** 正会員 大阪大学溶接工学研究所 茨木市美穂ヶ丘
団そのものを正確にとらえ得ないので，西る故障を整 理しても，それを単純に他の事例に適用できない。周 知のように, 機械や構造物の部材の強度問題では組織 敏感性が重要であり, 信頼度を問題にする領域は分布 のすそ野であるから，故障物理の認識がなければ現実 的にはこのすそ野の分布を適確につかむことは不可能 である。また，機械や構造物を省資源の考兄方から見 て, 最近長期使用が再び要望されるようになってきて いるが，これる後述の劣化現象に対する理解が充分で なければならない。長期使用の場合, 供用中検査が重 視されるようになってきたが，前述のように機械や構 造物の多種多様な使用条件下にあっては, 使用中検査 に基づいて適確な判断を下すためにも故障物理に対す る認識が充分必要である.

\section{2 故障物理に基づく解析}

\section{$2 \cdot 1$ 強度と寿命の統計的分布と故障率}

材料強度の統計的分布については本講座の第 1 講で 既に述べられているので, ここでは以下で用いる最小 限必要なことのみを述べる. ここでも前述の材料強度 （抵抗）を（応力の単位を有する）確率変数Xで表す。 （外からメなる応力が作用するときを考光，）このとさ

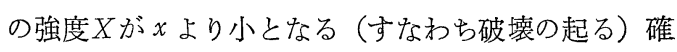
率は

$$
F_{R}(x)=\operatorname{Prob}[X \leqq x]=\int_{0}^{x} f_{R}(\xi) d \xi
$$

である.ここでRは強度（抵抗）の意味をもつ添字で ある、この $F_{R}(x)$ を狭義の破壊確率または $x$ の（累 積）分布関数と呼び, それの余関数

$$
L_{R}(x)=1-F_{R}(x)=\operatorname{Prob}[X>x]=\int_{x}^{\infty} f_{R}(\xi) d \xi
$$

を狭義の非破壊確率（生存確率）または信頼度（reliability function) などと呼ぶ.ここで $f_{R}(x)$ は

$$
f_{R}(x)=d F_{R}(x) / d x=-d L_{R}(x) / d x
$$

で示される確率密度または密度関数である.（図の関 係は本講座第 1 講を参照されたい.)

信頼性工学では上述の強度 $X$ の代りに時間 $T$ （疲労 の場合には絽返し数 $N$ ）を考光る場合が多く,このと きの時刻 $t$ に和ける単位時間当りの故障または破損の 
発生率を $\lambda_{T}(t)$ と記し，これを故障率（破損率, failure rate) または危険度 (risk hazard) などと呼 ぶ. $\lambda_{T}(t)$ と上述の $F_{T}(t)$ および $f_{T}(t)$ との関係は

$$
\begin{array}{r}
\lambda_{T}(t)=f_{T}(t) /\left\{1-F_{T}(t)\right\}=f_{T}(t) / L_{T}(t) \\
F_{T}(t)=1-L_{T}(t)=1-\exp \left[-\int_{0}^{t} \lambda_{T}(\xi) d \xi\right]
\end{array}
$$

で表される．ここで $L_{T}(t)$ は時刻 $t$ まで故障や破損 の起らない確率, $f_{T}(t)$ は時刻 $t と t+d t$ の間に故障 や破損の起る確率が $f_{T}(t) d t$ となるような密度関数で ある．信頼性工学では $\lambda_{T}(t)$ は図 1 のようないわゆる 浴槽曲線 (bath-tub curve) で説明される. すなわち, $\lambda_{T}(t)$ の変化の過程には (I) 初期故障, (II) 偶発故障 および（III）摩耗（または劣化）故障の 3 期がある.

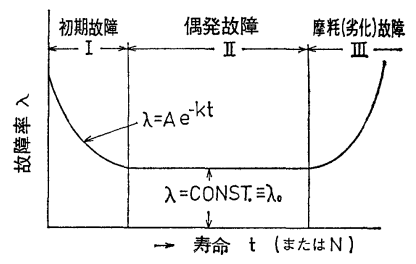

図 1 浴槽曲線

(これについての詳細は文献に譲るが)，第 I 期はふつ ら $\lambda_{T}(t)=A e^{-k t}$ なる指数関数で近似され, この段階 の故障は製造過程の不備によるものとされ, debugging または burn-in といらプロセスで除くことがで きる. 第 II 期は寿命の大部分を占める過程で， $\lambda_{T}(t)$ $=$ const. $\equiv \lambda_{0}$ となるもので, 定常確率過程の一種であ る. ここでは故障事象は全くランダムなので，実際に 起った故障を整理して故障の統計的分布をもとめ, $\lambda_{T}(t)$ を例えばポアソン分布の母数などとして統計的 に処理を行らしか方法がない，第吕期は時間に依存す る劣化過程であるので, 摩耗, クリープまたは疲労な ぞの破損の機構を追求する必要がある.ここにも故障 物理の認識が必要である.

\section{$2 \cdot 2$ 分布のすそ野での確率の推定}

本講座の第 1 講で述べられている材料強度の分布は よく用いられる特定の分布（正規，対数正規，または ワイブル分布など）で近似されるが，それらの分布は 何れも分布の中心傾向 (平均值, 中央値または最頻值 など）の近傍で当てはまりの良いように近似されるも ので, 分布のすそ野での当てはむりは一般に良くない ので，ここでの破壊確率 $F_{R}(x)$ を精度高く推定する ことが困難であることは当然考えられるが， $F_{R}(x) の$ 推定值とその信頼限界をもとめる方法が全くないわけ ではない，それらの方法は分布やその母数などに関係 なく，すと野での確率とその信頼限界をるとめるもの で, non-parametric method とか distribution-free method と呼ばれる. ここでは紙面の都合上, 参考文
献を挙げるに留める。

しかしいずれにせよ，すそ野の確率を推定すること はできても，その值の誤差の範囲は非常に広いので, このような方法を用いることが有効か否かは一考を要 する．材料強度に関しては強いものほど組織敏感性は 著しく, 通常, 信頼度を問題にする領域は分布のすと 野であり, 前述の故障物理の認識が欠けていると現実 的にはこのすそ野の分布を適確につかむことは不可能 であろう。

\section{$2 \cdot 3$ 安全率と破壊確率}

既に本講座第 1 講で述べられているように, 部材の 破壊確率と安全率との関係は図 2 に示すいわゆる応 力-強度模型 (stress-strength model, 略称 S-S モデ ル）でよく説明される. すなわち, 最大応力 $x_{S}$ の分 布 $f_{S}(x)$ と強度 $x_{R}$ の分布 $f_{R}(x)$ を共通の $x$ 軸にと った同一の線図に分布曲線で示し，その相対位置で破 壊や安全性を論じるものである. 図のように二つの分 布曲線がそのすそ野で交っているときには，この交っ ている領域では応力が強度を越えているから破壊が起 る.ゆえに，この場合の破壊確率（広義）は

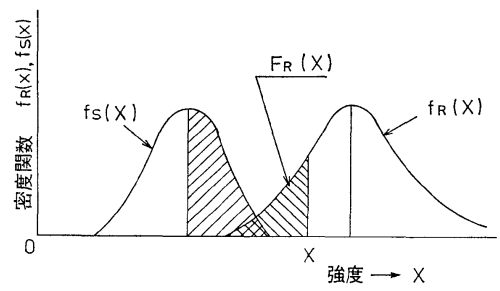

図 2 応力-強度モデル

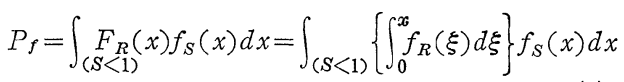

となる.このとき安全率は $S=x_{R} / x_{S}$ であり, $\bar{S}=\bar{x}_{R} /$ $\bar{x}_{S}$ をたは $\widetilde{S}=\tilde{x}_{R} / \tilde{x}_{S}$ を中央安全率 (central safety

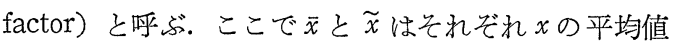
と中央值である．応力 $x_{S}$ を確定值と考えるときには

$$
P_{f}=\int_{0}^{x} f_{R}(\xi) d \xi=F_{R}(x)
$$

となって(1)式に一致する. $F_{R}(x)$ を狭義の破壊確率と 呼ぶゆ光んである. (6)式の $P_{f}$ は図 2 の両曲線が交っ ている領域に和ける両曲線下の面積に相当する.

構造物などでは上述の安全率の代りに安全余裕 (safety margin) $Z=[$ 強度 $]-[$ 最大応力 $]=x_{R}-x_{S}$ を 用いることが多い. また, S-S モデルで, 最大応力, 強度双方とも対数正規分布するといら取扱いが（特に 構造物の信頼性解析では)よく行われており,このとき 対数安全率 :

$$
\left.\begin{array}{ll} 
& \log S=\log \left(x_{R} / x_{S}\right)=\log x_{R}-\log x_{S} \\
\text { 平 } & \text { 均 : } \overline{\log S}=\overline{\log x_{R}}-\overline{\log x_{S}} \\
\text { 分 } & \text { 散 : } \sigma_{\log S^{2}}=\sigma_{\log x_{R}}{ }^{2}+\sigma_{\log x_{S}}{ }^{2}
\end{array}\right\}
$$


となり, 対数安全率は対数強度と対数（最大）応力に よる安全余裕に他ならない。

以上のように, 信頼性設計では上述の中央安全率を とるときの破壊確率は(6)式で与兄られる. 換言すれば 破壊確率（または信頼度）と結びつけられた安全率， すなわち統計的安全率を用いることになる，以前設計 者のとり方に任せられていた信用のない（古典的）安 全率と異り，この統計的安全率は破壊確率や信頼度の データの裏づけのある安全率ということができよう.

\section{$2 \cdot 4$ スキャターファクター}

最近航空機の信頼性設計では scatter factor (略称 S.F.) と呼ばれる一種の寿命安全率が用いられている. この係数は一般には

$$
\text { S. F. }=\tilde{N} / N_{0}
$$

で表される，ここで $\tilde{N}$ は寿命の代表値（平均値等）， $N_{0}$ は安全寿命（安全な繰返し数の上限）である. 具 体的には人によってまちまちであり, 紙面の都合上以 下に二例を示すに留める。

Halpin はこれを次式で表した.

$$
\text { S. F. }=\hat{x}_{0} / x_{L}=\left(\tilde{x}_{0} / x_{L}\right) \cdot\left(\hat{x}_{0} / \tilde{x}_{0}\right)
$$

ここで $\hat{x}_{0}$ は寿命 $x$ 確率変数とするワイブル分布の 尺度母数の最尤推定值， $\tilde{x}_{0}$ は信頼係数 $\gamma$ に対応する 下限片側区間推定値， $x_{t}$ は信頼度 $L$ に対応する 寿命 $x$ の值である。また，Freudenthal は次のように表し た。

$$
\text { S. F. }=\hat{\beta} / y_{1}
$$

ここで $\hat{\beta} は （$ 標本サイズ $n$ の）寿命に関する 2 母数ワ イブル分布の最尤推定值, $y_{1}$ は fleet size $m$ の time to first failure (略称 TTFF) である.（詳細は紙面の 都合で省略. 文献 8）を参照されたい。

\section{$2 \cdot 5$ 影響度評価 (重要度判定, sensitivity an- alysis)}

破壊確率や信頼度のような統計的に安全性を評価す る量は各種要因の影響をうけ，これらの要因を入力と するときの応答と考光ることがでさる。これら各要因 の影響度評価は以下のようにして行われる. 一般に要 因 $x_{\imath}(i=1,2, \cdots \cdots)$ の応答 $Z$ (performance function）に及ぼす寄与が

$$
z=f\left(x_{1}, x_{2}, \cdots, x_{\imath}, \cdots, x_{n}\right)
$$

のように既知であるときにはこれの平均と分散は

$$
\begin{aligned}
\bar{z}= & f\left(\bar{x}_{1}, \bar{x}_{2}, \cdots, \bar{x}_{\imath}, \cdots, x_{n}\right) \\
\operatorname{Var}(z)= & \sum_{i=1}^{n} \alpha_{\imath}{ }^{2} \cdot \operatorname{Var}\left(x_{\imath}\right) \\
& +\sum_{i=1}^{n} \sum_{\jmath=1}^{n} C_{\imath \jmath} \operatorname{Cov}\left(x_{\imath}, x_{\jmath}\right) \\
\cong & \sum_{i=1}^{n} \alpha_{\imath}{ }^{2} \operatorname{Var}\left(x_{\imath}\right)
\end{aligned}
$$

ここで $\alpha_{2}=\left(\partial f / \partial x_{2}\right) x_{=} \bar{x}_{2}$ である. また，変動係数=
標準偏差/平均は

$$
v_{z}^{2}=\sum_{i=1}^{n} c_{\imath}^{2} v_{x}^{2}
$$

である.ここで $c_{2}=\left(\partial f / \partial x_{2}\right) \cdot\left(\bar{x}_{2} / \bar{z}\right)$ を影響度指数 (sensitivity index) と言い, 要因 $i$ の寄与の程度を示 す.一般には(12)式のような関係のわかっていないこと も多く、そのようなときには一次近似として線形回帰 模型を用いて要因分析をやればよい。な拉，信頼性工 学では上述の performance function $z$ にはふつら破 壊確率や信頼度をとることが多い（詳細は文献 9）参 照のこと.)

\section{$2 \cdot 6$ 安全指標}

信頼性工学に基づいた設計は多くの問題のゆ兑にな かなか普及していない，文礼光土木構造物設計の分 野で害際に応用されている信頼性工学では, 最近, 2 次モーメント法と拡張信頼性理論の二つが提案されて いる.

(a) 2 次モーメント近似法 (Cornell による)

強度や寿命などの統計的分布関数は一般には不明な 場合が多い. Cornell は不確定性をもつ変数の確率的 性質を（分布関数を精確に求めることなく）平均と分 散だけで表す近似方法を提唱し，これの設計への応用 を示した. (12)式の performance function $z$ が平均 $\mu_{z}$ と分散 $\sigma_{z}{ }^{2}$ を有して分布するとき， $z$ が前述の安全 余裕 $z=R-S$ ( $R$ は強度, $S$ は最大応力）ならば

$$
\beta=\mu_{z} / \sigma_{z}=1 / v_{z}
$$

なる安全指標（safety index）を考光る．ここで $v_{z}$ は $z$ の変動係数である. $z \leqq 0$ すなわち $R \leqq S$ は破壊を 意味する，信頼性設計としては $z>0$ でなければなら ないから

$$
\mu_{R}>\mu_{S}+\beta \sqrt{\sigma_{R}^{2}+\sigma_{S}^{2}}
$$

とすれば良い， $z$ が対数安全率 $\log (R / S)$ の場合には

$$
\begin{gathered}
\beta=\mu_{\log z} / \sigma_{\log z} \\
\mu_{R}>\mu_{S} \exp \left[\beta_{\sqrt{v_{R}}+v_{S}{ }^{2}}\right]
\end{gathered}
$$

となる. $\beta$ は $z$ が $\mu_{z}$ より $\sigma_{z}$ の何倍だけ $z$ の低い方 に離れているかを示すもので，以上二つの場合とも $\beta$ の值が大きいほど安全に対する余裕は大きいといらこ とになる。現行設計規準では $\beta=2.5 \sim 5.0$ が矛盾な しとされている。（ふつう統計学では $\beta=3$ をよく使 う.）（詳細は文献 11）飞譲る.）

(b) 拡張信頼性理論 (Ang ら)

本理論は不確定要因を“客観的不明量”と “主観的 不明量”に大別して信頼性設計を扱うものであり，(a) の場合の安全指標 $\beta$ の代りに量的表現困難な主観的不 明量を含む判定係数を用いるものである。（詳細は文 献 11）参照)

$$
3 \text { ベイズ法の適用 }
$$

強度や寿命などの確率変数の統計的分布を近似する 
に充分なデータは得られないのがふつうである.この とき, 類似の現象に関する事前情報と手もちの少標本 データだけでベイズの定理を用いて統計的分布を予測 する方法がベイズ法 (Bayesian approach) である. (紙面の都合上, 詳細は割愛する。詳細は文献 8）～9） および 12)〜14）を参照されたい。）

\section{4 強度劣化過程}

部材の寿命を扱うとき， $2 \cdot 1$ 節の図 1 亿示した 浴 槽曲線で第亚期にあたる強度劣化過程が特に重要であ る. それは寿命およびその統計的分布が残留強度とそ の分布および（最大）応力とその頻度分布の両者の時 間的变化に依存するからであり，このことは $2 \cdot 3$ 節 から明らかである。これに関して従来から応力一抵抗 模型 (stress-resistance model, 略してS-Rモデル) が用いられる. 以下これについて説明する.この概念 は応力ピーク值が先のときの残留強度值を超過すると 破壊が起るとする一種の破壊規準がその基礎になって いるものである.このため, このモデルでは（残留） 強度の応力作用に伴ら変化がその統計的分布とともに 求められていなければならない。

いま, ピーク応力（または荷重）を時間の関数とし て $S(t)$ と記し, 一方, 材料の残留強度 (抵抗) をこ れも時間の経過とともに变化するものとし, $R(t)$ と 記す。このとき S-Rモデルは

$$
S(t) \geqq R(t)
$$

となったときに破壊が起るといら概念を基礎としてい る.（疲労のときには時間 $t$ の代りに絽返し数 $N$ を る.）図 3 は一定応力振幅の繰返し応力が作用したと きの S-R モデルの考方方を示す. 15 . この図では残留強 度は確定值として扱われ，その統計的分布が考学られ ていない，図4 はランダム応力の作用するときのS-

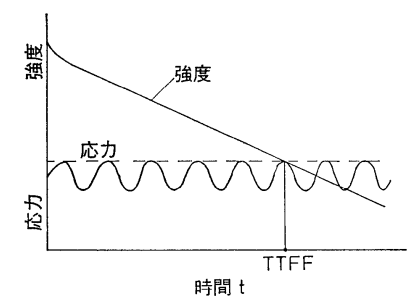

図3 応力-抵抗モデル（一定応力振幅）

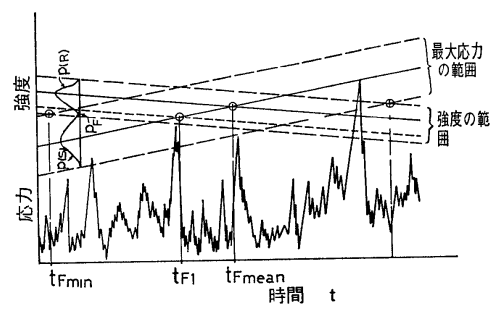

図4 応力-抵抗モデル（ランダム応力）
$\mathrm{R}$ モデルの説明図で，これに扔いては（残留）強度の 統計的分布が考光られているが，な和その分布は時間 的変化しないとしている. 実際には残留強度の分布 は時間とともに変化すると考えられ，ばらつきが時間 とともに増すこともある.

S-R モデルに関して従来から多くの研究結果が発 表されている.（文献17)の末尾渗考文献りストが載 っている.）このらち疲労き裂進展過程を扱ったもの が最も多く, また, 最近の研究のほとんぞが, 複合材 料の疲労過程に関するものである.

Halpin はき裂長さ $l(t)$ の進展速度を Paris 流に

$$
d l(t) / d t=B_{1}\{G(t)\}^{m}
$$

と表しこれを積分して任意の時刻 $t$ に打けるき裂長 さ $l(t)$ の式をもとめ, 残留強度 $Y(t)$ が $\{l(t)\}^{-1 / 2}$ に比例するとして残留強度の時間的変化の式を導いた。 さらに強度の初期值の分布を 2 母数ワイブル分布と拈 いて任意の時刻 $t$ 亿和将る残留強度 $Y(t)$ の分布関数 を次式のように導出した。

$R_{Y}(y)=\exp \left[-\left\{\frac{y^{2(m-1)}(m-1) B_{6} x_{\max ^{2 m}\left(t-t_{0}\right)}}{y_{0}^{2(m-1)}}\right\}^{\alpha_{f}}\right]$

ここで $R_{Y}(y)$ は残留強度 $Y$ に関する信頼度である. $Y(t)$ の分布関数の形は複雑であるが, $\{Y(t)\}^{2(m-1)}$ の分布は 3 母数ワイブル分布となっている. 時刻 $t$ の 変化に伴い，ばらつきを示す形状母数 $\alpha_{f}$ は変化しな い. 前述の上うにこの点は事実に反すると思われる.

最近, 疲労き裂の進展過程をマルコフ過程として扱 った論文がいくつか発表されている. Bogdanoff と

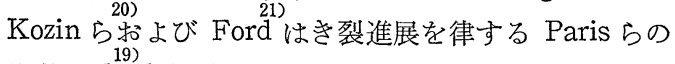
指数則 $d a / d N=C(\Delta K)^{m}$ を基礎にして Fokker-Planck 式を用いてき裂長さの分布関数の時間的変化を導いた。 また Bogdanoff と Kozin らはき裂進展則等の関係を 一切仮定せず，離散的な時間飞衫ける損傷の状態を離 散的段階で表し，これのとりらる推移確率行列を用い たマルコフ連鎖を扱ってあるき裂長さに達するまでの 時間や任意の時刻での損傷の平均と分散をるとめてい る.

\section{5 欠陥分布と破壊確率の評価}

この問題に関する二つの論文を紹介する，その第一 は D. Shaffer による「圧力容器健全性に対する欠樎 評価手順の確率的アセスメント」と題するものである. これに括いては最終さ裂長さ $a_{f}$ と限界き裂長さ $a_{c}$ の間にき裂に対する一種の安全率を考劣ている.すな わち， $\lambda_{1} a_{f}<\lambda_{2} a_{c}$ ならば修理は必要なしとしている。 $\lambda_{1} / \lambda_{2}=m$ とすると $a_{f}<a_{c} / m$ で, らつう ASME Sect. XI, IWB-3600 requirement によりタイプAとB （正常㧍よび異常状態）に対しては $m=10$, タイプ C とD(緊急㧊よび損傷状態) そ対しては $m=2$ として 
いる. 安全評価の度合は確率 $P=\operatorname{Prob}\left[a_{f}{ }^{T}<a_{c}{ }^{T} \mid \lambda_{1} a_{f}{ }^{*}\right.$ $\left.<\lambda_{2} a_{2}{ }^{*}\right]$ ，（ $T$ は真， * は実測を表す）であるが， $P^{\prime}$ $=P_{1} P_{2}=\operatorname{Prob}\left[a_{f}{ }^{T}<\lambda_{1} a_{f}{ }^{*}\right] \times \operatorname{Prob}\left[\lambda_{2} a_{c}{ }^{*}<a_{c}{ }^{T}\right] \cong \operatorname{Prob}$ $\left[a_{f}{ }^{T}<\lambda_{1} a_{f}{ }^{*}<\lambda_{2} a_{c}{ }^{*}<a_{c}{ }^{T}\right]$ を用いて， $P^{\prime} \leqq P$ であるか ら $P^{\prime}$ を評価すれば良いとしている. (1) $P_{1}$ の評価は $a_{f}{ }^{T}=a_{0}+I$ ( $a_{0}$ 注初き裂長さ, $I$ は $a_{0}$ 以後のき裂長 さ增分）として Paris らの指数則（前出）からIの值 を計算し，Iの分布を対数正規分布として $P_{1}$ の值を もとめている. (2) $P_{2}$ の評価沉つてて， $a_{c}{ }^{*}=f\left(K_{\mathrm{Ic}}{ }^{*}\right.$, $\left.\sigma_{c}\right)$ 施よび $a_{c}{ }^{T}=f\left(K_{\mathrm{I}}, \sigma_{c}\right), \quad\left(\sigma_{c}\right.$ は限界応力）より $P_{2}=\operatorname{Prob}\left[\lambda_{2} a_{c}{ }^{*}<a_{c}{ }^{T}\right]=\operatorname{Prob}\left[\lambda_{2} K_{\mathrm{Ic}}<K_{\mathrm{Ic}}{ }^{T}\right]$ によりも そめるとしている． $\lambda_{2}$ に関しては $\lambda_{2}=a_{c}^{*} / a_{c} * *$ (* は平均， **は下限を表す）とし，これょり Prob $\left[\lambda_{2} a_{c}{ }^{* *}\left\langle a_{c}{ }^{T}\right]=\operatorname{Prob}\left[a_{c}{ }^{*}\left\langle a_{c}{ }^{T}\right]\right.\right.$ としている. この 值を評価するのに $2 \cdot 2$ 節で触れた non-parametric method を用いる. すなわち, $\operatorname{Prob}\left[\operatorname{Prob}\left(K_{\mathrm{Ic}}>x\right)=\right.$ $\delta]=1-\alpha$ とし， $\delta=\alpha^{1 / n}$ の式を用いて計算する. 例 壳ば，危険率 (有意水準) $\alpha=5 \%$, 標本サイズ $n=94$ とすると $\delta=97 \%$ となる. この研究の結果としてmの 值により $P^{\prime}$ の值は変化し， $m \geqq 2$ では $\operatorname{Prob}\left[a_{f}^{T}<\right.$ $\left.m a_{f}^{*}\right]=1$ であるが, $1<m<2$ の範囲では研究されて いない，今後研究すべきこととして，上述の分布によ らない non-parametric な方法より parametric な方 法を用いることと， $a_{\mathrm{c}}$ の下限值よりむしろ平均值を用 いるべきこと拈よび $1<m<2$ の場合を研究すること などを挙げている.

もら一つは M. J. Dufresne Kよる「加圧水型原子 炉容器破壊確率」と題する論文である. まず LWR プ ラントの破壊確率の評価法として(1)プラントデータを 用いる統計的方法 (WASH 1400 では許容破摆確率 $10^{-7} \sim 10^{-6}$ ととっている) と(2)確率的破壊力学を用い る方法の二つを挙げ，後者では今後もっと精度を上げ ることができるとし，その方法として(i)計算機コード の開発，(ii)データの収集とその処理方法，および(ii)実 験プログラムの費用的支援を挙げている．以下この論 文で述べている方法のあらましを紹介する。 まず計算 機コードの表示は(a)欠陥の寸法と位置, (b)き裂進展速 度，预よび(c)荷重経歴についてなされる．欠陥分布と 寸法の決定に関しては第一段階として修理前に欠陥分 布を決めるべきこと，第二段階として非破壊検査を行 って実際の信頼度を説明できるようデータを修正する ことを決めている. 検定にはフランスの CPFC, 米国 の ASME Sect. XI の二つの方法を採用，全長 $338 \mathrm{~m}$ の溶接線について解析し, 結果が検定方法に敏感なこ とが示された．欠陷密度は（検定方法によるが），溶接 線 $1 \mathrm{~m}$ 当り平均 1.2 個である. 修理前の欠陥の分布関 数や製造者からの分布データも示され，後者では欠陥 の分布関数は溶接ごとに異っている．欠俩位置につい
ては, 深さ方向には久陷分布を示さず, 溶接線対称軸 からの相対位置によって密度が異り, 界面で密度が大 きく, 対称軸上で小さい. 欠陥長さ関しては, 修理 前の欠陥長さ分布が示され，長さは $3 \mathrm{~mm} \sim 1.4 \mathrm{~m}$ の 範团にわたって分布して和り，分布は対数正規分布で 近似される，また，深さ依存性も示されている，超音 波探傷ではX線のそれより欠陥は長目に出ているので, 主としてこれのみを考虑し, X線データは補充情報と すべきであるとしている．欠陷幅の分布についてはほ とんど情報がない，最大幅は $3.5 \mathrm{~mm}$ である， 欠陥 が重なっているところではそれぞれの幅の和をとって 幅としている. 欠陷長さに及ぼす幅の影響も示されて いる．計算機コードに導入すべき欠陥分布としては， 超音波とX線のどちらかで欠陥が発見されたらとれを 考慮し，両方で測られたら長い方をとる. 分布法則に は修正係数を導入し， $\chi^{2}$ 分布を使用し，99\% 信頼度 レベルで欠陷長さを求めている. 結果として出てきた 長さを15２0\%增にするようにすすめている. 非破壇 検查装置の精度に関してはデータが活とんどない. 欠 陷長さは実際より $5 \%$ 短く出ると注意している。陥 検出確率 (detectability) については現在 34 の機構の 共同研究で a large international program PISC が 作られつつある. 許容欠陥寸法は修理前の欠陥分布を CPFC の許容基準を用いて修正して決めている。最 後に, 破壊解析はParis らの指数則（前出）を用い， 確率的な形で欠陥を評価し，ヒストグラムを示してい る. 放射線によるぜい化は壁厚さと時間から， $K_{\mathrm{IC}}=$ $K_{\mathrm{I} C R}+\Delta K_{\mathrm{I} C}$ をこれの関数としてもとめることにより 評価する. 破壊の判定は破填じん性規準で行われ，条 件付破壊確率がもとめられ，これに及洔す各因子の影 響度評価が行われている.

\section{6 信頼性工学的手法に基ついた破壊力学の応用}

これに関しては以下の二つの研究を紹介する。

(a) Lidiard-Williams の研究

この研究では予め存在するき裂と欠陷の進展による 原子炉容器の破壞確率の解析が行われ, 破壊確率の代 りに破損率（前出）をとり，これに及ぼす(i)供用に先 立つ予備圧力テスト，(ii)き裂の incidence, 形状およ び寸法の分布, (iii)材料破壊じん性 $K_{\mathrm{IC}}$ の分布, (iv)超 音波検查などの破損率に及ぼす影響度評価を行ってい る．破壊は正常の運転（添字 $N$ ）と緊急または損傷状 態（添字 $E$ ) 飞分影らている. 破壊確率 $P_{f}$ の代り 飞密度関数 $Q=d P_{f} / d t$ が用いられ, 次式で与兄られ ている.

$Q f^{N}=\sum_{r} Q^{(r)}=-\sum \int f\left(K_{\mathrm{I} C}\right) N^{(r)}\left\{\xi^{-1}(a)\right\} \frac{d \xi^{-1}(a)}{d t} \cdot d K_{\mathrm{I} C}$

ここで, $K_{\mathrm{I}}=K_{\mathrm{I}}{ }^{(r)}\{\sigma, \xi(x)\} ，\left(\xi\right.$ は初期き裂長さ $a_{0}$ 
をもつき裂の時刻 $t$ での長さ)， $Q_{f}{ }^{N}$ の計算には(1)破 壊規準 $K_{\mathrm{I}} \geqq K_{\mathrm{I} C}$, (2)容器母集団特性, および(3)過渡応 力状態が考慮される.き裂の寸法と incidence の分 布をき裂深さの分布で代表し，これには(i)一つの連続 した表面直線き裂，および(ii)一つの半だ円表面き裂の 二つを考えている. これによる応力拡大係数 $K_{\mathrm{I}}$ と破 壊じん性 $K_{I C}$ とは独立としている．き裂の存在確率 密度関数 $N(x)$ は容器当りのき裂平均数の相対頻度 であり, これの関数形には Marshall らの研究や Becher-Pedersen の研究で用いられたものを引用し ている. 破壊じん性の分布 $f\left(K_{\text {I } C}\right)$ として正規分布と ワイブル分布の 2 種が仮定された.き裂進展則には Paris らの指数則 $d a / d N=C(\Delta K)^{m}$ を仮定している. 圧力容器は一定応力振幅に加光て過渡応力をらけ, 予 めき裂を生ずるが，以後の疲労き裂進展に著しい影響 を与えないと仮定し，また最大の過渡応力は供用前の 圧力テストで生ずるとされた． $K_{\mathrm{I}} や \xi\left(a_{0}, t\right)$ が部分 的にしかわかっていないので， $P_{f} や Q_{f}$ を正確に評 価することは困難なので, 単純かつ多くの場合につき 実験し, 破壊確率密度関数に及ぼす各要因の影響度を もとめた。 具体的には (i) $Q_{f}$ に対する容器の各場所 (記号 $r$ )，(ii)き裂進展則の係数 $C$, (iii)破壊じん性分布 $f\left(K_{\mathrm{I} C}\right)$ の仮定, (iv) $K$ 值の式 $K_{\mathrm{I}}=$ const $\cdot \sqrt{\bar{a}}$ c const ・ $a$ の選択等による影響度を調べている.（詳細と研 究結果は文献23)を参照のこと).

(b) 北川-久田の研究

この研究は線形破壊力学に基づいてき裂進展におけ る信頼度の評価を欠陷検出確率とベイズの手法を用い て行い, 欠陥成長, 非破壊検査, 供用中検査を考慮し, ISI をらける構造物の信頼性解析手法を体系化したも のである、また，これは条件付確率を用いる Shinozuka の方法を体系だてて発展させたものである.

ISI を考觉た信頼性解析：まずこの論文では半径 $a_{0}$ の 半円型表面き裂を想定し，これが相似形を保ちつつ成 長し板厚 $t$ に達したときを破壊とするといらモデルを 仮定した．線形破壊力学のき裂進展則より応力拡大係 数 $K$ を用いて $d a / d T=f(K)$ とした. 検査によって発 見可能な最小欠陥寸法を $a_{2}$ とすると, 最長検査間隔 は $T^{*}=\int_{a_{2}}^{t} d a / f(K)$ とする必要がある。 $a_{0}$ に対し初期 欠陷存在確率密度 $G_{0}\left(a_{0}\right)$ を考元, 欠陥検出には欠陥 発見確率 $P(D \mid a)$ なる条件付確率を想定した。 以下の 二つのモデルを考光, $G_{0}\left(a_{0}\right)$ と $(k+1)$ 回目の欠陷検 査まで破壊しない確率 $L\left(k, T_{0}\right)$ の両者が二つのモデ ルで異るとした.すなわち，(i)補修モデル……こで はき裂を発見して処置した後はその箇所は無欠陥の状 態になるものとしている.すなわち, $L\left(k, T_{0}\right)=1$ で ある. 供用前検查のあるとさ $G\left(a_{0}\right)=G_{0}\left(a_{0}\right)$, 供用前
検査のないとき $G\left(a_{0}\right)=P\left(\bar{D} \mid a_{0}\right)\left(G_{0}\left(a_{0}\right)+\delta\left(a_{0}\right) \int_{0}^{\infty} P(D \mid\right.$ x) $G_{0}(x) d x$ である. (ii)部品交換 モデル……これにお いてはき裂を発見して処置後はその箇所に開始前と同 じ $G_{0}\left(a_{0}\right)$ に従うき裂が 1 個存在する状態になるとし ている. すなわち, $L\left(k, T_{0}\right)=1-P_{f}(k), \quad G\left(a_{0}\right)=P$ $(\bar{D} \mid a) G_{0}\left(a_{0}\right) / \int_{0}^{\infty} P\left(\bar{D} \mid a_{0}\right) G_{0}\left(a_{0}\right) d a$ (ベイズの定理) であ る. (2)他の確率モデルへの応用 : 以上のモデルを以下 のような場合に応用している。（i)不規則荷重下では $L\left(k ， T_{0}\right)$ 等には破損率（前出）を導入すればよい. (ii)供用中にき裂の発生するモデルを初期モデルとして 扱らことができる.すなわち，ここでは寸法 $a_{0}$ のき 裂が存在し, これが架空の減小関数 $H$ に従い時間 $t_{0}$ 経過後に $a^{*}$ の寸法に成長したと考学る. (iii)さらに複 雑な場合, 「初期き裂も存在し, き裂発生も起る場合」 とか，「不等時間間隔の検査が実施される場合」にも 応用できる. (3)き裂進展則 $d a / d N=C(\Delta K)^{m}$ を用い, これを積分して時刻 $T$ に拉けるき裂深さ $a$ と $T$ との関 係をもとめることができる. (4)初期き裂寸法分布 $G_{0}$ $\left(a_{0}\right)=\left(a_{0}-a_{l}\right)^{q-1}\left(a_{u}-a_{0}\right)^{r-1} / B(q, r) \cdot\left(a_{n}-a_{l}\right)^{q+r-1}$ なるベータ分布を用いている. (5)欠陷発見確率を $P$ $(\bar{D} \mid a)=\left\{\left(a-a_{1}\right) /\left(a_{2}-a_{1}\right)\right\}^{d}$ とする.ただし， $a_{1}<a<$ $a_{2}$, (6)代表的解析例と信頼度を与える ISI 効果および その他の影響因子の評価として $(\mathrm{i})$ モデルの違いと PSI (供用前検査), (i1)初期き裂寸法分布, (iii) ISI の精度, 保守と設計条件について各種要因との関連で調べてい る. また, (iv)各種要因の影響度評価には $2 \cdot 5$ 節の方 法を用いている.（詳細と研究の結果については文献 25)に譲る.)

\section{7 最近の新しい試み}

機械・構造物は種々の構成要素の組合せを基礎とし てきわめて複雑なシステムを構成している. 信頼性モ デルを作成するためには対象とするシステムの構造を 明らかにすることがすず必要である.

機械・構造物に限らず，今日の工学技術は一般に構 成要素の組合せをいろいろと変化させることにより新 しい複雑なシステムをつくる例が多い.こうした背景 から近年構成要素間の結合関係を追求し複雑なシステ ムの構造を明らかにしようとする学問が発達してきた。 これがグラフ理論と呼ばれる数学の一分野である. グ ラフ理論では点と線で構成された図形に持ける結合関 係を調べる. この点や線には問題に応じて適当な性質 を付与できるので, グラフ理論は応用範囲がきわめて 広い。

信頼性工学においては解析の手法はきわめて発達し ているが，解析の前提となる信頼性モデルの作成手法 については必ずしも体系化されているとは言い難い. そこでグラフ理論を応用してモデル化の手法を体系化 
しよらとする試みが最近行われるようになってきてい る.

信頼性工学でよく用いられるグラフ的表現に信頼性 グラフがある. システム信頼度は，信頼性グラフの入 力と出力を結ぶいくつかの通路の組合せのらち少くと も一つの通路に含まれるすべての要素が所定の要求機 能を満す確率として求められる. 信頼性グラフは決し て要素の現実の配置の表現ではなく, 各要素の機能を 考光て始めて定義されることに注意しなければならな い.すなわち信頼性グラフは信頼性モデルを与えるが その作成手順はあまり明りょらではない。

そこでより実用的な，一定の手順により信頼性モデ ルが作成できる手法の開発が試みられている. その一 つが Fault Tree Analysis (FTA) である. 信頼性グ ラフは正常モードを対象とするが，FTA は故障モー ドを対象とする，FTA ではある特定の故障モードを 頂上事象として選び, それがシステムの構成要素のど のような状態の組合せによって生じるかを段階的に考 えてゆくことにより信頼性モデルを構築する。な拉, Fault Tree は信頼性グラフと双対関係にあるので, 故障モードでなく正常モードを考光同一の手法を適用 すれば信頼性グラフと等価な結果が得られる.

他の一つの方法ではシステムの故障を事象間の 2 項 関係 (因果関係) を基礎としてネットワークに表現す る.このネットワークに和ける故障の流れとして種々 の故障モードが求められる. この方法では事象を例え ば工程と対応させることにより施工に技ける品質管理 と直接関連づけられる利点がある.

FTA もネットワーク法も事象（グラフの点）の定 義が明解であり，それが物理的実体ではなく「状態」 の表現であることを明示している点が重要である．信 頼性グラフはこの点が必ずしも明確ではない。このよ らに事象の定義がはっきりしているので, FTA やネ ットワーク法ではグラフ理論のパスセットやカットセ ットの概念を利用して，事象が必ずしも定量化されて いない場合でも，ぞのようにすれば信頼性が確保でき るかの意志決定を行うことが可能となる. したがって これらの方法は信頼性モデルの作成手順を与えるとい ら観点からも重要であるが，また別に定量的解析が難 しい場合でも信頼性を確保するための方策が決定でき るといら点で重要である. 事実定量化が容易でない事 例に対しこれらの手法を適用し信頼性を確保しょうと する試みが最近いくつか行われている.

紙面の都合上各方法の詳細を述べられないので, 読 者はそれぞれの箇所にあげた文献を参照されたい。

\section{参 考 文 献}

1）西島 敏, 城野政弘, 材料, 31, 409 (1982).
2) Bazovski, I., 桜田猛訳, “信頼性の理論と応用” (1963) 日刊工業新聞社

3) Freudenthal, A. M., J.M. Garrelts, and M. Shinozuka, Proc. ASCE, 92-ST1 167 (1966).

4) Shaffer, D. H., W. H. Bamford, and M. Jouris, IME Paper C14/80, 45 (1980).

5) Shinozuka, M., and A. Nishimura, Tech. Rep., Inst. Study of Fatigue and Reliability, Columbia University, N.Y., 14 (1965).

6）鍋谷清治，複合材料の信頼性研究分科会資料， No. 12 (1980).（末公表）

7) Hájek, J., 丘本 正他訳, “ノンパラメトリック統計 学” (1974) 日科技連

8) 中川隆夫, 材料, 28, 2 (1979).

9）岡村弘之, 板垣 浩, “強度の統計的取扱い”, 234(1979) 培風館

10）ドレーパー，スミス，中村慶一訳，“応用回粫分析”, (1967) 森北出版

11）土木学会, 構造物の安全性・信頼性, 土木学会, 15 and 45 (1976).

12）中川隆夫, 信頼性強度設計に関する基礎講習会, 日本機 械学会中国四国支部，13 (1976).

13）中川隆夫，信頼性工学の基礎と構造工学的応用に関する 講習会, 日本材料学会関西支部, 14 (1979).

14）藤井 進, 中川隆夫, 橋本和彦, 日本機械学会諭文集, 45, 516 (1979).

15) Haviland, R.P., "Engineering Reliability and Long Life Design” (1964) Nostrand

16) Freudenthal, A. M., Reliability Approach in Structural Engineering, 3 (1975) 丸善

17）中川隆夫，第 3 回設計に和ける信頼性工学シンポジウム 前刷, 38 (1981) 日本材料学会

18) Halpin, J.C. et al., AFML-TR-72-289, W-P AFB (1972).

19) Paris, P. C., and F. Erdogan, Trans. ASME 85-D, 528 (1963).

20) Bogdanoff, J.L. et al., J. Appl. Mech., ASME 452,$246 ; \mathbf{4 5}-4,251 ; \mathbf{4 5}-4,733$ (1978); 47-1, 40 (1980); Engrg. Fract. Mech., 14-1, 59 (1981).

21) Ford, D. G., ARL-STRUC-REP-369 (1978).

22) Dufresne, M. J., IME Paper C13/80, 38 (1980).

23) Lidiard, A. B., and M. Williams, J. of British Nuclear Energy Soc., 16, 207 (1977); Conf. A Theor. Anal. of Reliability of PWR Press. Vessels, IME, London, 1 (1978).

24）北川英夫，久田俊明，日本機械学会論文集， 45, 1033 (1979).

25) Shinozuka, M., AFFDL TR-76-31 (1976).

26) Busacker, R. G., and T. L. Saaty, 矢野健太郎, 伊理 正夫訳, “グラフ理論とネットワーク/基礎と応用” (1976) 培風館

27) Berge, C., 伊理正夫他訳, “グラフの理論” (1976) サ イエンス社

28）Kaufmann, A., 国冯清典監訳, “グラフの理論” (1976) 東洋経済新報社

29) Preparata, F.P., and R.T. Yeh, 榎本彦衛訳, “離散 構造入門” (1980) 日本コンピュータ協会

30）塩見 弘, “信頼性工学入門” (1974) 丸善

31）井上威恭, “FTA 安全工学” (1979) 日刊工業新聞社

32）福田収一, 溶接学会誌, 50, 169 (1981).

33）福田収一, 材料, 30, 1232 (1981).

34) 福田収一, 日本機械学会論文集 (A編)，47，172(1981).

35) Masters, J.E., et al., Composites, April (1977).

36) Fukuda, S., "Failure Prevention and Reliability1981", 81 (1981) ASME

37) Marriot, D. L., and N.R. Miller, "Failure Prevention and Reliability-1981", 197 (1981) ASME 